\title{
The Mostafa Maged hemostatic flipping-over technique to control and prevent the post-partum bleeding from the lower uterine segment in placenta previa cases
}

\author{
Mostafa Maged Ali* \\ Department of Obstetrics and Gynecology, Ministry of health-Fayoum, Egypt
}

Received: 27 October 2021

Accepted: 13 December 2021

\section{*Correspondence:}

Dr. Mostafa Maged Ali,

E-mail: Supermostafa200@yahoo.com

Copyright: ( ) the author(s), publisher and licensee Medip Academy. This is an open-access article distributed under the terms of the Creative Commons Attribution Non-Commercial License, which permits unrestricted non-commercial use, distribution, and reproduction in any medium, provided the original work is properly cited.

\begin{abstract}
Post-partum hemorrhage is still a headache to all obstetricians around the whole world. Every obstetrician exerts his own full effort to control bleeding which can occur post-partum by applying all maneuvers to preserve the fertility and the uterus for the patient. We demonstrate a new technique (Mostafa Maged) technique to control and prevent postpartum hemorrhage. It is so simple maneuver and easy to be applied within short period of time. Satisfactory hemostasis can be assessed after application. The aim of this technique is to see the Success in Controlling and prevention of the bleeding from placenta previa cases from lower uterine segment. The average duration of this new technique is (5-7) minutes. The results have shown that the hysterectomy done to one patient with new technique (1/13) (7.6\%) cases because of the uncontrollable bleeding, blood was creeping down from the flipped sutured lower uterine segment. All of patients are introduced to the operating room as first-time cesarean section. One patient (7.6\%) out of thirteen patients were tachycardiac post-operatively due to the more loss of blood as the new (Mostafa Maged) technique took a long time in these two patients ( 8 minutes). The tests of success were expected if hemostasis is done by the bimanual compression at first place.
\end{abstract}

Keywords: Post-partum hemorrhage, Placenta previa, Lower uterine segment, Cesarean section, Mostafa Maged technique

\section{INTRODUCTION}

Placenta previa is the complete or partial covering of the internal OS of the cervix with the placenta. It is a major risk factor for postpartum hemorrhage and can lead to morbidity and mortality of the mother and neonate. The presence of placenta previa can also increase a woman's risk for placenta accrete spectrum (PAS). ${ }^{1}$

Uncontrolled postpartum hemorrhage from placenta previa or PAS may necessitate a blood transfusion, hysterectomy thus leaving the patient infertile, admission to the ICU, or even death. ${ }^{1}$

Approximately $94 \%$ of patients were diagnosed using ultrasound (bedside, in the radiology department or fetal- maternal unit), and only $6 \%$ needed MRI to confirm the diagnosis. Clinically, $83 \%$ of patients presented with painless vaginal bleeding, and $17 \%$ discovered incidentally.

Caesarean section is recommended for delivery in cases of placenta previa. Women with a low-lying placenta have at least $60 \%$ chance of a vaginal birth, but should be monitored for post-partum haemorrhage. ${ }^{2}$

Obstetric hemorrhage is the most common and dangerous complication of childbirth. Traditionally, postpartum hemorrhage (PPH) has been defined as greater than 500 $\mathrm{mL}$ estimated blood loss in a vaginal delivery or greater than $1000 \mathrm{~mL}$ estimated blood loss at the time of cesarean delivery. ${ }^{3}$ 
The aim of reporting these cases is to reveal our experience with this new technique to prevent and control the extreme bleeding post-partum.

\section{CASE SERIES}

\section{Patients (population characters)}

Thirteen cases of young aged ladies, as discussed in Table 1 , with placenta previa (anteriorly located) were managed by a new technique (Mostafa Maged technique) in order to prevent and control post-partum hemorrhage from the lower uterine segment.

All patients were informed carefully about their situations and the risks of their conditions properly, and they were informed about if cesarean hysterectomy would be done in cases of severe hemorrhage. The mean age of patients is (26.5 years old). It is the first time of cesarean section for all patients. All patients post-operatively were vitally stable except one patient.

The first case has a placenta previa marginal is as shown in Figure 1, and, the second case has a placenta previa centralis as shown in Figure 2. And others were similar to those as in pictures.

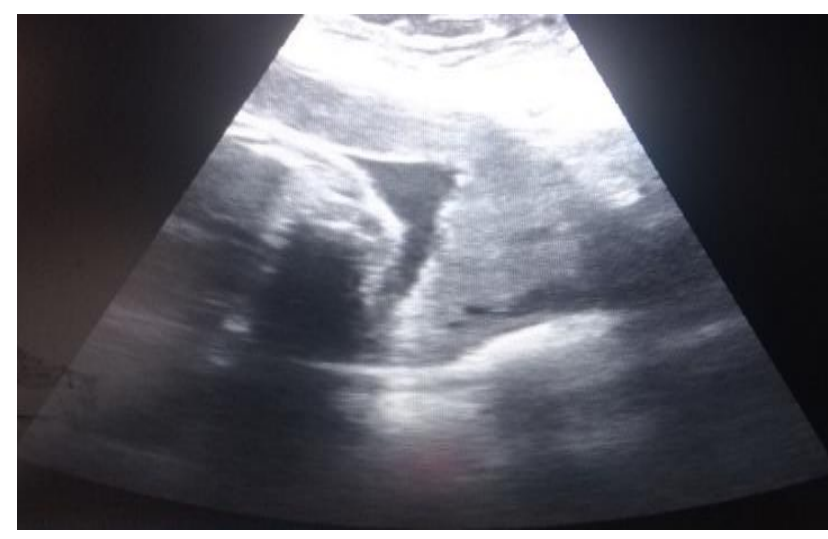

Figure 1: Anteriorly located placenta marginalis of the first case.

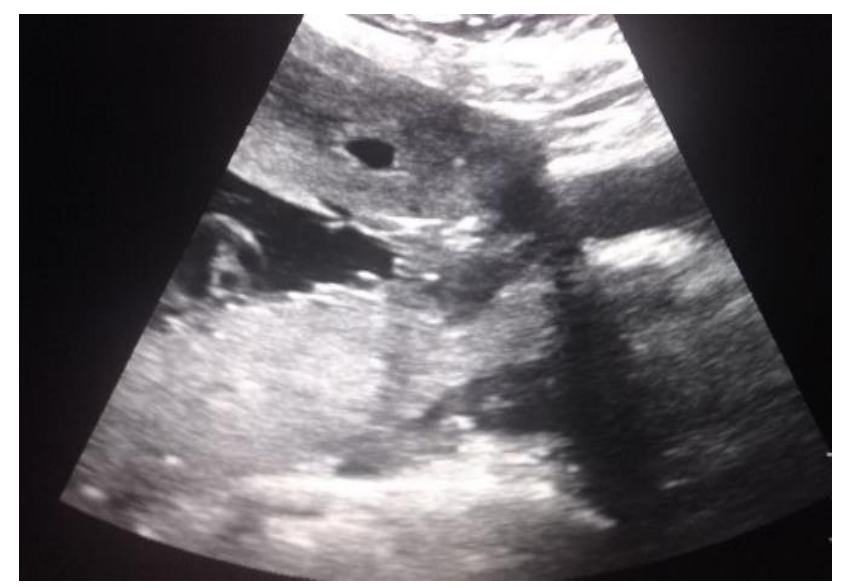

Figure 2: Placenta previa centralis of the second case.

\section{Description of the surgical technique}

The principle of this technique is compressing the anterior part of lower uterine segment against each other. It has been done to those thirteen patients immediately after extraction of fetus and placenta.

The following steps are involved in the competent application of Mostafa Maged technique: Illustrated as well on a sponge module of uterus by Figures 3-6.

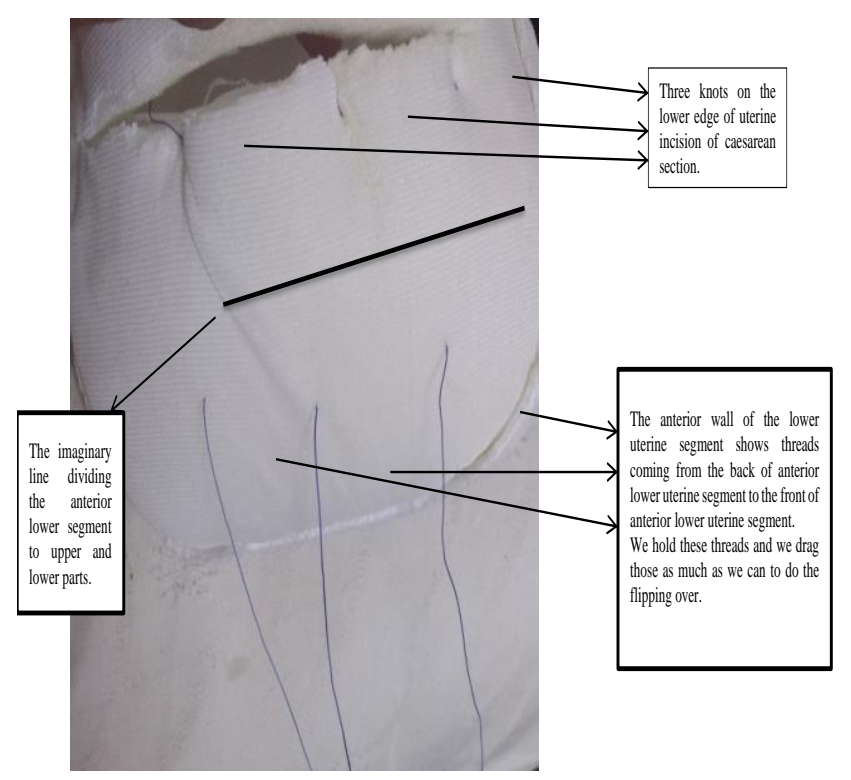

Figure 3: The anterior wall of the lower uterine segment shows threads coming from the back of anterior lower uterine segment to the front of anterior lower uterine segment.

We hold these threads and we drag those as much as we can to do the flipping over.



Figure 4: The intra-cavitary view.

The posterior wall of the lower uterine segment shows the three threads extended backwards from the three knots in the lower edge of uterine incision and after introducing the three needles through the posterior wall to the anterior wall of the anterior part of lower uterine segment preparing for flipping-over by pulling the needles as much as we can. 


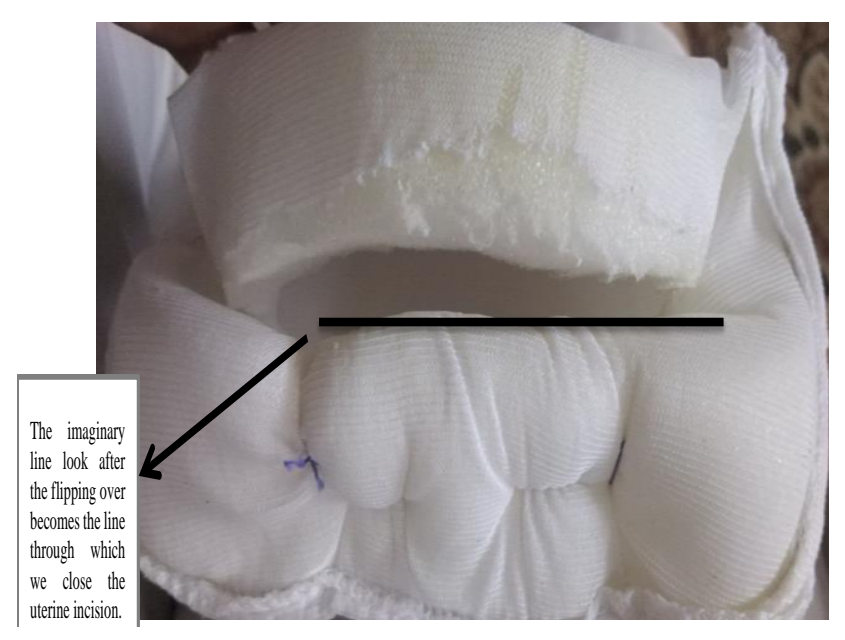

Figure 5: This is the view of lower uterine segment after the flipping over of the upper part of anterior lower uterine segment over the lower part of the anterior lower uterine segment and after plication of lower uterine segment.

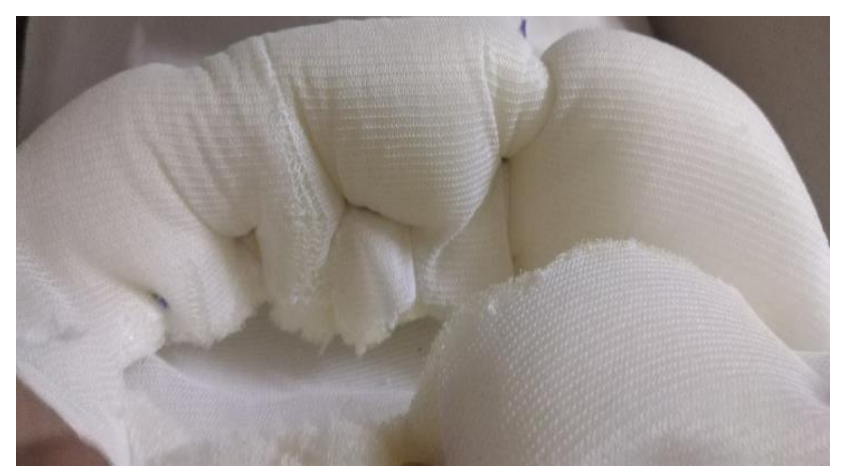

Figure 6: Intra-cavitary view.

This is the view of lower uterine segment from the intra-cavitary angle (intra-uterine view, the posterior part of lower uterine segment, after the flipping over of the upper part of anterior lower uterine segment over the lower part of the anterior lower uterine segment and after plication of lower uterine segment.

Some patients under spinal anesthesia and the others were under general anesthesia, then, catheterization of the bladder of the patient, the abdomen is opened by an appropriate Pfannenstiel incision.

On introduction into the abdominal cavity, dissection of the bladder downwards, and then making an incision in the lower segment of the uterus, then the uterus is evacuated from the fetus and placenta.

Ligation of uterine arteries on both sides is applied before proceeding and after extraction of fetus and placenta.

We start searching of the bleeding spots, then, trying to stop these bleeding areas by packing/ suturing these areas.

The lower segment was bleeding so we tried to do bimanual compression of the anterior and posterior parts of lower uterine segments to test if our (Mostafa Maged technique) is useful in these cases or not (by observing if the bleeding is minimized or stopped or not by compression) as if it is minimized so our technique has a high chance to be effective.

The whole technique depends on the anterior lower uterine segment by dividing the anterior lower uterine segment by an imaginary line in two halves, then, we turned over (flipped) the upper part of the lower uterine segment onto the lower part of the lower uterine segment from the inside of uterine cavity.

We do this turnover (flipping ) by our hands and holding the imaginary line by two Allis forceps and by making three knots by three needles in the lower edge of the uterine incision and we enter the needles of (absorbable 70 $\mathrm{mm}$ rounded-bodied vicryl 1) simultaneously into the lower segment through the uterine cavity, at the same level of, the inside wall of lower uterine segment in order to drag the upper (half) part of the lower uterine segment on the lower part of lower uterine segment (sandwich-like), and after this maneuver the bleeding is re-evaluated again.

Third, we stitch the both sides of the flipped lower uterine segment by (absorbable $70 \mathrm{~mm}$ rounded-bodied vicryl 1), then we do plication of the anterior lower uterine segments to strengthen the wall of the flipped lower uterine segment and secure the tension.

Fourth, we close the caesarean scar by suturing the already-flipped lower uterine segment onto the upper uterine segment. The two cases we suture the flipped lower uterine segment onto the anterior surface of upper uterine segment in two layers then secured by U-shaped sutures.

Fifth, after closing the uterine incisions, we place a drain in the Douglas pouch and to observe if there was huge amounts of bleeding or not.

We report the results of these thirteen cases of placenta previa with hemorrhage in the field of caesarean surgery managed by the (Mostafa Maged) technique, and, the results are in the Table 1 . So, this technique can be used to control or prevent the impending post-partum hemorrhage.

The average duration of this new technique is (5-7) minutes. The results have shown that the hysterectomy done to one patient with new technique (1/13) $(7.6 \%)$ cases because of the uncontrollable bleeding, blood was creeping down from the flipped sutured lower uterine segment. All of patients are introduced to the operating room as first-time caesarean section. One patient $(7.6 \%)$ out of thirteen patients were tachycardiac post-operatively due to the more loss of blood as the new (Mostafa Maged) technique took a long time in these 2 patients ( 8 minutes).

The tests of success was expected if hemostasis is done by the bimanual compression at first place. 
Table 1: Cases series and results of the new technique.

\begin{tabular}{|c|c|c|c|c|c|c|c|c|}
\hline $\begin{array}{l}\text { Age } \\
\text { (years) }\end{array}$ & Parity & $\begin{array}{l}\text { Gestational age } \\
\text { (weeks) }\end{array}$ & $\begin{array}{l}\text { Intensive care } \\
\text { admission for } \\
\text { just regular } \\
\text { follow-up }\end{array}$ & $\begin{array}{l}\text { Current mode } \\
\text { of delivery }\end{array}$ & $\begin{array}{l}\text { Outcome immediate post- } \\
\text { operatively }\end{array}$ & $\begin{array}{l}\text { Hospital } \\
\text { stays } \\
\text { (days) }\end{array}$ & $\begin{array}{l}\text { Number of blood } \\
\text { units received }\end{array}$ & $\begin{array}{l}\text { Outcome of the } \\
\text { (Mostafa } \\
\text { Maged) new } \\
\text { technique }\end{array}$ \\
\hline 26 & Primigravida & 37 & $\begin{array}{l}24 \text { hr with } \\
\text { vitally stable }\end{array}$ & $\begin{array}{l}\text { Cesarean } \\
\text { section }\end{array}$ & $\begin{array}{l}\text { Good (post-partum } \\
\text { hemorrhage is stopped and } \\
\text { lax abdomen and minimal } \\
\text { vaginal bleeding post } \\
\text { cesarean section) }\end{array}$ & 4 & $\begin{array}{l}3 \text { units of blood } \\
\text { transfused }\end{array}$ & $\begin{array}{l}\text { Preserving the } \\
\text { uterus and } \\
\text { fertility }\end{array}$ \\
\hline 28 & Primigravida & 38 & $\begin{array}{l}24 \mathrm{hr} \text { with } \\
\text { vitally stable }\end{array}$ & $\begin{array}{l}\text { Cesarean } \\
\text { section }\end{array}$ & $\begin{array}{l}\text { Good (post-partum } \\
\text { hemorrhage is stopped and } \\
\text { lax abdomen and minimal } \\
\text { vaginal bleeding post } \\
\text { cesarean section) }\end{array}$ & 3 & $\begin{array}{l}3 \text { units of blood } \\
\text { transfused }\end{array}$ & $\begin{array}{l}\text { Preserving the } \\
\text { uterus and } \\
\text { fertility }\end{array}$ \\
\hline 24 & Primigravida & 36 & $\begin{array}{l}24 \mathrm{hr} \text { with } \\
\text { vitally stable }\end{array}$ & $\begin{array}{l}\text { Cesarean } \\
\text { section }\end{array}$ & $\begin{array}{l}\text { Good (post-partum } \\
\text { hemorrhage is stopped and } \\
\text { lax abdomen and minimal } \\
\text { vaginal bleeding post } \\
\text { cesarean section) }\end{array}$ & 2 & 2 units of blood & $\begin{array}{l}\text { Preserving the } \\
\text { uterus and } \\
\text { fertility }\end{array}$ \\
\hline 22 & $\begin{array}{l}\text { Para two } \\
\text { normal } \\
\text { vaginal } \\
\text { delivery }\end{array}$ & 37 & $\begin{array}{l}24 \mathrm{hr} \text { with } \\
\text { vitally stable }\end{array}$ & $\begin{array}{l}\text { Cesarean } \\
\text { section }\end{array}$ & $\begin{array}{l}\text { Good (post-partum } \\
\text { hemorrhage is stopped and } \\
\text { lax abdomen and minimal } \\
\text { vaginal bleeding post } \\
\text { cesarean section) }\end{array}$ & 3 & 2 units of blood & $\begin{array}{l}\text { Preserving the } \\
\text { uterus and } \\
\text { fertility }\end{array}$ \\
\hline 29 & $\begin{array}{l}\text { Para one } \\
\text { normal } \\
\text { vaginal } \\
\text { delivery }\end{array}$ & 38 & $\begin{array}{l}24 \text { hr with } \\
\text { vitally stable }\end{array}$ & $\begin{array}{l}\text { Cesarean } \\
\text { section }\end{array}$ & $\begin{array}{l}\text { Good (post-partum } \\
\text { hemorrhage is stopped and } \\
\text { lax abdomen and minimal } \\
\text { vaginal bleeding post } \\
\text { cesarean section) }\end{array}$ & 3 & $\begin{array}{l}1 \text { unit of blood } \\
\text { transfusion }\end{array}$ & $\begin{array}{l}\text { Preserving the } \\
\text { uterus and } \\
\text { fertility }\end{array}$ \\
\hline 30 & Primigravida & 37 & $\begin{array}{l}24 \mathrm{hr} \text { with } \\
\text { vitally stable }\end{array}$ & $\begin{array}{l}\text { Cesarean } \\
\text { section }\end{array}$ & $\begin{array}{l}\text { Good (post-partum } \\
\text { hemorrhage is stopped and } \\
\text { lax abdomen and minimal } \\
\text { vaginal bleeding post } \\
\text { cesarean section) }\end{array}$ & 2 & $\begin{array}{l}3 \text { units of blood } \\
\text { transfused }\end{array}$ & $\begin{array}{l}\text { Preserving the } \\
\text { uterus and } \\
\text { fertility }\end{array}$ \\
\hline 31 & $\begin{array}{l}\text { Para } 3 \text { normal } \\
\text { vaginal } \\
\text { delivery with } \\
\text { current history } \\
\text { of bleeding }\end{array}$ & 36 & $\begin{array}{l}24 \text { hr with } \\
\text { vitally stable }\end{array}$ & $\begin{array}{l}\text { Cesarean } \\
\text { section }\end{array}$ & $\begin{array}{l}\text { Good (post-partum } \\
\text { hemorrhage is stopped and } \\
\text { lax abdomen and minimal } \\
\text { vaginal bleeding post } \\
\text { cesarean section) }\end{array}$ & 3 & $\begin{array}{l}3 \text { units of blood } \\
\text { transfusion }\end{array}$ & $\begin{array}{l}\text { Preserving the } \\
\text { uterus and } \\
\text { fertility }\end{array}$ \\
\hline
\end{tabular}


Ali MM. Int J Reprod Contracept Obstet Gynecol. 2022 Jan;11(1):237-242

\begin{tabular}{|c|c|c|c|c|c|c|c|c|}
\hline $\begin{array}{l}\text { Age } \\
\text { (Years) }\end{array}$ & Parity & $\begin{array}{l}\text { Gestational age } \\
\text { (Weeks) }\end{array}$ & $\begin{array}{l}\text { Intensive care } \\
\text { admission for } \\
\text { just regular } \\
\text { follow-up }\end{array}$ & $\begin{array}{l}\text { Current mode } \\
\text { of delivery }\end{array}$ & $\begin{array}{l}\text { Outcome immediate post- } \\
\text { operatively }\end{array}$ & $\begin{array}{l}\text { Hospital } \\
\text { stays } \\
\text { (days) }\end{array}$ & $\begin{array}{l}\text { Number of blood } \\
\text { units received }\end{array}$ & $\begin{array}{l}\text { Outcome of the } \\
\text { (Mostafa } \\
\text { Maged) new } \\
\text { technique }\end{array}$ \\
\hline 33 & $\begin{array}{l}\text { Primigravida } \\
\text { with twins }\end{array}$ & 37 & $\begin{array}{l}24 \text { hr with } \\
\text { vitally stable }\end{array}$ & $\begin{array}{l}\text { Cesarean } \\
\text { section }\end{array}$ & $\begin{array}{l}\text { Good (post-partum } \\
\text { hemorrhage is stopped and } \\
\text { lax abdomen and minimal } \\
\text { vaginal bleeding post } \\
\text { cesarean section) }\end{array}$ & 1 & $\begin{array}{l}2 \text { units of blood } \\
\text { transfusion }\end{array}$ & $\begin{array}{l}\text { Preserving the } \\
\text { uterus and } \\
\text { fertility }\end{array}$ \\
\hline 28 & $\begin{array}{l}\text { Para one } \\
\text { normal } \\
\text { vaginal } \\
\text { delivery }\end{array}$ & 38 & $\begin{array}{l}24 \mathrm{hr} \text { with } \\
\text { vitally stable }\end{array}$ & $\begin{array}{l}\text { Cesarean } \\
\text { section }\end{array}$ & $\begin{array}{l}\text { Good (post-partum } \\
\text { hemorrhage is stopped and } \\
\text { lax abdomen and minimal } \\
\text { vaginal bleeding post } \\
\text { cesarean section) }\end{array}$ & 1 & $\begin{array}{l}2 \text { units of blood } \\
\text { transfused }\end{array}$ & $\begin{array}{l}\text { Preserving the } \\
\text { uterus and } \\
\text { fertility }\end{array}$ \\
\hline 27 & $\begin{array}{l}\text { Para one } \\
\text { normal } \\
\text { vaginal } \\
\text { delivery now } \\
\text { with Twins }\end{array}$ & 37 & $\begin{array}{l}24 \text { hr with } \\
\text { vitally stable }\end{array}$ & $\begin{array}{l}\text { Cesarean } \\
\text { section }\end{array}$ & $\begin{array}{l}\text { Good (post-partum } \\
\text { hemorrhage is stopped and } \\
\text { lax abdomen and minimal } \\
\text { vaginal bleeding post } \\
\text { cesarean section) }\end{array}$ & 2 & $\begin{array}{l}3 \text { units of blood } \\
\text { transfusion }\end{array}$ & $\begin{array}{l}\text { Preserving the } \\
\text { uterus and } \\
\text { fertility }\end{array}$ \\
\hline 25 & $\begin{array}{l}\text { Primigravida } \\
\text { with current } \\
\text { history of } \\
\text { bleeding pre- } \\
\text { termination }\end{array}$ & 35 & $\begin{array}{l}\text { Tachycardia } \\
\text { and pallor due } \\
\text { to anemia so } \\
\text { three units of } \\
\text { blood } \\
\text { transfused }\end{array}$ & $\begin{array}{l}\text { Cesarean } \\
\text { section }\end{array}$ & $\begin{array}{l}\text { Good (post-partum } \\
\text { hemorrhage is stopped and } \\
\text { lax abdomen as well as } \\
\text { minimal vaginal bleeding } \\
\text { post cesarean section) after } \\
\text { three units of blood } \\
\text { transfused post- } \\
\text { operatively }\end{array}$ & 3 & $\begin{array}{l}5 \text { units of blood } \\
\text { transfusion }\end{array}$ & Hysterectomy \\
\hline 20 & Primigravida & 38 & $\begin{array}{l}24 \text { hr with } \\
\text { vitally stable }\end{array}$ & $\begin{array}{l}\text { Cesarean } \\
\text { section }\end{array}$ & $\begin{array}{l}\text { Good (post-partum } \\
\text { haemorrhage is stopped and } \\
\text { lax abdomen as well as } \\
\text { minimal vaginal bleeding } \\
\text { post cesarean section) }\end{array}$ & One & $\begin{array}{l}2 \text { units of blood } \\
\text { transfusion }\end{array}$ & $\begin{array}{l}\text { Preserving the } \\
\text { uterus and } \\
\text { fertility }\end{array}$ \\
\hline 22 & Primigravida & 38 & $\begin{array}{l}24 \mathrm{hr} \text { with } \\
\text { vitally stable }\end{array}$ & $\begin{array}{l}\text { Cesarean } \\
\text { section }\end{array}$ & $\begin{array}{l}\text { Good (post-partum } \\
\text { hemorrhage is stopped and } \\
\text { lax abdomen as well as } \\
\text { minimal vaginal bleeding } \\
\text { post cesarean section) }\end{array}$ & 1 & $\begin{array}{l}3 \text { unit of blood } \\
\text { transfusion }\end{array}$ & $\begin{array}{l}\text { Preserving the } \\
\text { uterus and } \\
\text { fertility }\end{array}$ \\
\hline
\end{tabular}




\section{DISCUSSION}

The treatment and management of postpartum hemorrhage are focused on resuscitation of the patient while identifying and treating the specific cause. Maintaining the hemodynamic stability of the patient is important to ensure continued perfusion to vital organs. Ample intravenous (IV) access should be obtained. Careful direct assessment of cumulative blood loss is important, and a focus should be on the early initiation of protocols for the release of blood products and massive transfusion protocols. . $^{3,4}$

Placenta previa is a high-risk factor for massive $\mathrm{PPH}$, and increases the need for blood transfusion and cesarean hysterectomy. The most commonly accepted risk factors associated with PPH in cases with placenta previa are a complete placenta previa and anterior localization of the placenta. 5,6

The (Mostafa Maged) technique has been successfully used in the both described cases, this technique allows us to preserve the uterus and conserve the fertility. This technique is so simple and easy to be applied. This (Mostafa Maged) technique is used to control and to prevent the post-partum haemorrhage in a way as discussed above. In addition, the operating time is so short.

As we see in the illustrations, Figures of 3-6, Figures show the technique on a sponge module of uterus.

\section{CONCLUSION}

The invention of this new technique (Mostafa Maged technique) has shown its effectiveness in those thirteen patients in preventing and controlling the post-partum bleeding which can occur from the lower uterine segment in placenta previa cases. It is a new method which can be used as an alternative to the hysterectomy, it is promising, easy, cheap and effective technique.

Funding: No funding sources

Conflict of interest: None declared

Ethical approval: Not required

\section{REFERENCES}

1. Anderson-Bagga FM, Sze A. Placenta Previa. In: StatPearls. Treasure Island (FL): StatPearls Publishing. 2021.

2. Bhide A, Thilaganathan B. Recent advances in the management of placenta previa. Curr Opin Obstet Gynecol. 2004;16(6):447-51.

3. Wormer KC, Jamil RT, Bryant SB. Acute Postpartum Hemorrhage. In: StatPearls. Treasure Island (FL): StatPearls Publishing. 2021.

4. Maswime S, Buchmann E. A systematic review of maternal near miss and mortality due to postpartum hemorrhage. Int J Gynaecol Obstet. 2017;137(1):1-7

5. Oya A, Nakai A, Miyake H, Kawabata I, Takeshita TJ. Risk factors for peripartum blood transfusion in women with placenta previa: a retrospective analysis. Nippon Med Sch. 2008 Jun; 75(3):146-51.

6. Lee HJ, Lee YJ, Ahn EH. Risk factors for massive postpartum bleeding in pregnancies in which incomplete placenta previa are located on the posterior uterine wall. Obstet Gynecol Sci. 2017;60(6):520-6.

Cite this article as: Ali MM. The Mostafa Maged hemostatic flipping-over technique to control and prevent the post-partum bleeding from the lower uterine segment in placenta previa cases. Int J Reprod Contracept Obstet Gynecol 2022;11:237-42. 